\title{
ULTRASTRUCTURAL ASPECTS OF THE INTERCELLULAR BRIDGES BETWEEN FEMALE BEE GERM CELLS
}

\author{
PATRÍCIO, K. and CRUZ-LANDIM, C. \\ Departamento de Biologia, Instituto de Biociências de Rio Claro, UNESP, CEP 13506-900, Rio Claro, SP, Brazil \\ Correspondence to: Karina Patrício, Departamento de Biologia, Instituto de Biociências de Rio Claro, UNESP, \\ Avenida 24A, 1515, CEP 13506-900, Bela Vista, Rio Claro, SP, Brazil, e-mail: patricioka@ yahoo.com.br \\ Received October 24, 2003 - Accepted February 12, 2004 - Distributed February 28, 2006
}

(With 3 figures)

\begin{abstract}
The germline cells in the ovary of the female bee are interconnected by intercellular bridges kept open by cytoskeletal reinforcements in the plasmic membrane. These bridges among the germline cells display a dynamic behavior and probably act in the determination of the oocyte among the cells of the clone formed by the premeiotic mitoses, subsequently forming a pathway that enables the products synthesized by the nurse cells to reach the oocyte during its maturation. The cytoskeletal elements in the intercellular bridges of bee gonads are basically microfilaments and microtubules, but another type of filament (thick, of non-defined nature, associated with elements of the endoplasmic reticulum) is present in the bridges between the premeiotic cystocytes. This filament crosses the bridge, using microfilaments to fasten itself to the plasmic membrane. These filaments appear to control the span of the bridge. Upon completion of the proliferation phase the cystocytes take on a rosette shape, and a fusome formed by the convergence of the bridges appears at their center. The thick filaments are not present in this conformation. The differentiation of the oocyte and the nurse cells leads to a new change, in which the bridges are reoriented to convey the content of the future nurse cells to the oocyte.
\end{abstract}

Keywords: nurse cells, cyst, cytoskeleton, oocyte.

\section{RESUMO}

\section{Aspectos ultra-estruturais das pontes intercelulares} entre as células germinativas das fêmeas de abelhas

No ovário das abelhas as células germinativas e as células foliculares são interconectadas por pontes intercelulares mantidas abertas por reforços do citoesqueleto na membrana plasmática. As pontes entre as células germinativas têm comportamento dinâmico e provavelmente atuam na determinação do ovócito entre as células do clone formado pelas mitoses pré meióticas formando posteriormente uma via de transporte para que os produtos sintetizados pelas células nutridoras atinjam o ovócito durante sua maturação. Os elementos do citoesqueleto presentes nas pontes intercelulares das gônadas das abelhas são basicamente microfilamentos e microtúbulos, mas nas pontes entre os cistócitos pré-meióticos outro tipo de filamento (espesso de natureza não definida, associado a elementos do retículo endoplasmático) está presente, atravessando a ponte e prendendo-se através dos microfilamentos à membrana plasmática. Estes filamentos aparentemente controlam o vão da ponte. Terminada a fase de proliferação os cistócitos tomam a forma de uma roseta e um fusoma, formado pela convergência das pontes, aparece no centro desta. Nesta conformação os filamentos grossos não estão presentes. Nova mudança ocorre com a diferenciação do ovócito e das células nutridoras, com a reorientação de todas as pontes de maneira a canalizar o conteúdo das futuras células nutridoras para o ovócito.

Palavras-chave: célula nutridora, cisto, citoesqueleto, ovócito. 


\section{INTRODUCTION}

The substances exchanged among the cells that make up a tissue, an organ, or the organism as a whole are essential for its harmonious operation and for determining the specificity of its functions. The gonads contain two cell lines with interdependent functions: the germ cell line from which the gametes originate, and the somatic cell line which provides support.

In female insects with meroistic ovaries, each primary oogonium in the germarium is divided by mitosis, thereby resulting in two cells. One of these cells preserves its identity as a primary oogonium or stem cell, while the other differentiates into a secondary oogonium, called a cystoblast or mother cell, which produces cystocytes by successive cellular divisions with incomplete cytokinesis. These cells, which are interlinked by cytoplasmic bridges, constitute the cysts in the germarium (Cassidy \& King, 1972; Cruz-Landim, 1978; King \& Akai, 1982; Staurengo Da Cunha, 1981; Zacaro \& Cruz-Landim, 1996; Zacaro, 1999). Once the cycle of mitotic divisions (a characteristic of the species) is completed, one or more cyst cells enter the meiotic prophase, originating pre-oocytes, while the others assume the nursing function. Hence, the nurse and oocyte cells belong to the same line; they are clones resulting from the differentiation of cells in the same cyst.

Even when more than one cyst cell enters meiosis, each cyst will produce only one oocyte, while the nurse cells remaining in the polytrophicmeroistic ovaries (present in the hymenopterans) accompany the oocyte in the vitellarium.

The intercellular bridges between cells are supported by cytoskeletal reinforcements that enable and direct the flow of cytoplasmic compounds among the cystocytes (King, 1970; King et al., 1982; King \& Büning, 1985; Zacaro \& CruzLandim, 1996; Zacaro, 1999), which is vital for the maintenance of synchronous cellular division and, later, in the oocyte differentiation process.

Cooley \& Theurkauf (1994) described three phases in the differentiation of the oocyte in the cysts of D. melanogaster. In the first phase, a cytoplasmic asymmetry appears that defines which cell will create the oocyte. In the second phase, the microtubules of the fusome reorganize to form a polarized cytoskeleton. The fusome formed by the set of cystocyte bridges is centered in the cyst area, and the oocyte becomes the cystocyte that is bound to the others by the larger number of intercellular bridges. In the third phase, when cellular division has been completed, the fusome allows for the transport of proteins, mRNA and organelles among the cells of the cyst.

This paper describes the ultra-structural features of the intercellular bridges which occur among the germ cells of the reproductive system of female bees and the characteristics of the localization and organization of the cytoskeletal elements underlying the exchanges that take place among them.

\section{MATERIAL AND METHODS}

Ovaries of queens and workers of Scaptotrigona postica and Apis mellifera L. bees were obtained from colonies kept in the vivarium of UNESP's Rio Claro Institute of Biosciences, SP, Brazil. The material studied here consisted of ovaries from newly-emerged and laying queen bees and from nursing worker bees.

The ovaries were removed from the insects in buffered saline solution and fixed with $2 \%$ glutaraldhyde and $4 \%$ paraformaldehyde in $0.1 \mathrm{M}$ sodium cacodylate buffer $\mathrm{pH} 7.4$ for $2 \mathrm{~h}$ at $4{ }^{\circ} \mathrm{C}$. After fixation, each insect was washed twice in buffer for 15 min and post-fixed in $1 \%$ osmium tetroxide in the same buffer for $2 \mathrm{~h}$, again washed twice in buffer, and then contrasted in $2 \%$ uranyl acetate in $10 \%$ alcohol for $6 \mathrm{~h}$. The ovaries were then dehydrated in a series of increasing concentrations of acetone ( $70 \%$ to $100 \%$ ), infiltrated and embedded in Epon-araldite. Polymerization was carried out in an oven at $60{ }^{\circ} \mathrm{C}$ for $24 \mathrm{~h}$.

$0.5-1 \mu \mathrm{m}$ thick sections were cut and stained with Azure II and methylene blue to locate the most suitable region for the investigation. The ultra-thin sections were placed in copper grids and contrasted with lead citrate. The ovaries were analyzed and photographed using a Philips transmission electron microscope.

\section{RESULTS}

The intercellular bridges in ovaries of Scaptotrigona postica and Apis mellifera queens and worker bees were studied. Despite the degree of development reached by the ovaries in the 
different castes, their germ cell organization and development follow the same pattern. The bridges interconnecting the germ cells in the ovarian cysts, which result from mitosis with incomplete cytokinesis occurring during the proliferative phase of the secondary oogonia (cystoblast), therefore link sister cells - the cystocytes (Fig. 1). In the initial divisions, the cystocytes are linked to each other by short wide bridges, so that their nuclei are close to the bridges. This condition is also due to the small amount of cytoplasm in these cells (Figs. 1a and 1b). These bridges contain two types of reinforcements: 1) electron-dense microfilaments arranged in a ring immediately beneath the plasma membrane, forming a belt around the bridge area, and 2) thick filamentous

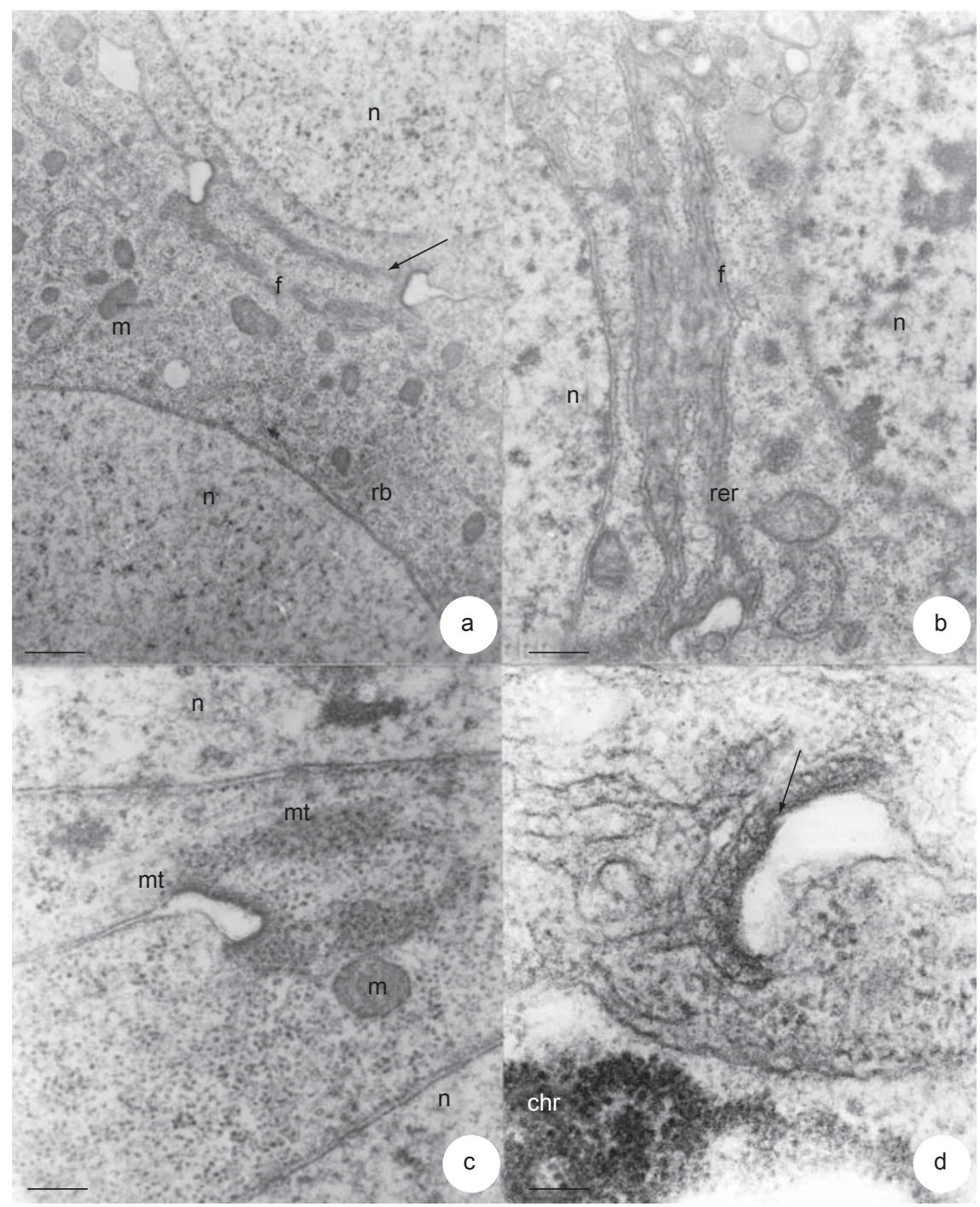

Fig. 1 - TEM image of intercellular bridges between cystocytes in A.mellifera ovary. a) Reinforcement that maintains the ring canal, visible as an electron density in the membrane (arrows) and bundles of filaments (f) that cross the bridge; b) Cisternae of rough endoplasmic reticulum (rer) crossing the bridge; c) Cross-section of thick filaments shown as electron densities connected to the ring reinforcement and associated microtubules $(\mathrm{mt})$; and d) Enlargement of the ring canal reinforcement (arrow) showing the attachment of the reticulum. $\mathrm{chr}=$ chromatin; $\mathrm{f}=$ filaments; $\mathrm{m}=$ mitochondria; $\mathrm{n}=$ nuclei; $\mathrm{rb}=$ ribosomes. Bars of Figs. $1 \mathrm{a}=1 \mu \mathrm{m}, 1 \mathrm{~b}=3 \mu \mathrm{m}, 1 \mathrm{c}=4 \mu \mathrm{m}, 1 \mathrm{~d}=4 \mu \mathrm{m}$. 
reinforcements intercalated with cisternae of the rough endoplasmic reticulum, which cross the bridges and are bound to the area of the membrane reinforced with microfilaments (Fig. 1b). Two main bundles of these thick filaments exist, extending throughout the sister cystocytes (Figs. 1a, 1b and 1c).

In some cases, in the bridge gaps contain free ribosomes and polysomes, mitochondria and microtubules, apparently without preferential orientation (Fig. 1c). In some of the bridges, or in some of their developmental phases, the reticulum cisternae in this region are smooth, often containing fibrillar material in their lumens. A cisterna of this membranous reticulum appears to cover the internal contour of the bridge wall (Fig. 1d).

Mitosis takes place inside compartments limited by somatic cells and cyst cells. As the number of cystocytes in the compartment increases, the bridges between the cells are rearranged, shifting to the center of the cyst to form the central fusome, while the cystocyte bodies with their nuclei shift to the periphery of the cyst (Fig. 2a).

The central fusome, which is the point of convergence of all the bridges in this rosette phase, is considered a specific ovarian organelle and is formed by the narrowing and stretching of these bridges between the cystocytes. The walls of the fusome remain reinforced by rings of microfilaments, but

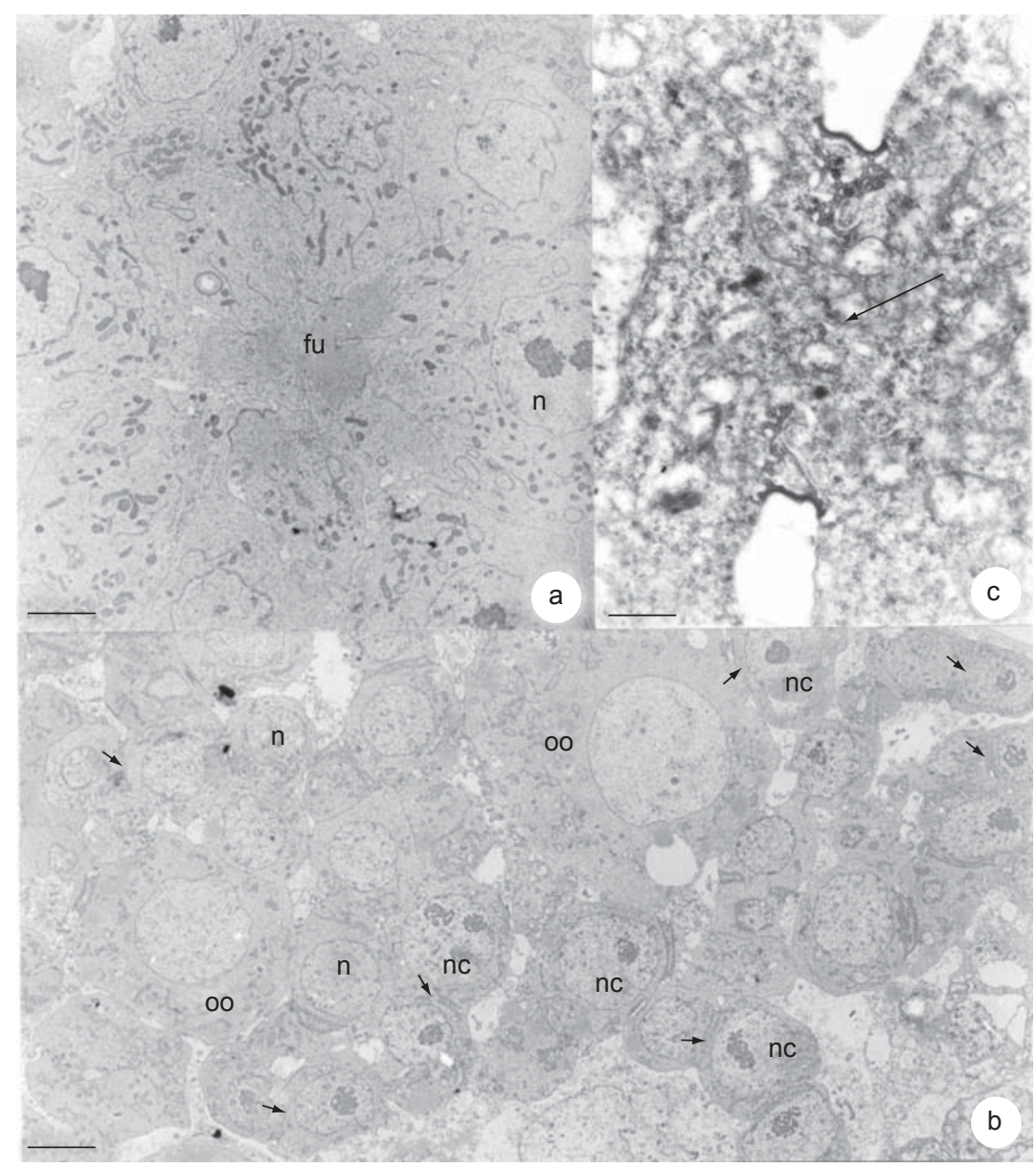

Fig. 2 - TEM image depicting the relationships among the cystocytes: a) Cyst showing the inner fusome (fu); b) Beginning of the oocyte (oo) differentiation in the cyst, showing rearrangement of the cystocyte's future nurse cells (nc) and connecting bridges (arrow); and c) Bridge already modified, typical of the connections among the nurse cells (arrows). $\mathrm{n}=$ nuclei. Bars of Figs. $2 \mathrm{a}=1 \mu \mathrm{m}, 2 \mathrm{~b}=1 \mu \mathrm{m}, 2 \mathrm{c}=3 \mu \mathrm{m}$. 
the thick internal filaments disappear or become disarranged. The fusome area presents a cytosol containing a fine felt of microfilaments almost entirely organelle-free except for the presence of a smooth endoplasmic reticulum. The region of each cystocyte near the fusome area is rich in Golgi complexes and mitochondria.

A new rearrangement of the cystocytes in the cyst occurs when an oocyte is differentiated among them. This cell, a primary oocyte, becomes much larger than the others and is located distally in relation to them (Fig. 2b). Because only one cell of the cyst becomes an oocyte, the remaining cells in the cyst become nurse cells (Fig. 2b), which again rearrange in response to bridge displacements that place them in an apical position in relation to the oocyte. Thereupon, the oocyte begins to present a crown of small cells at the apical pole, which are linked to each other and to the oocyte by bridges (Fig. 2b). In this stage, the oocytes are in the meiotic prophase, which can be confirmed by the presence of synaptonemal complexes between the homologue chromosomes. Like in other animals, the oocyte settles into the diplotene of the meiotic prophase.

After differentiation, the oocyte enters the maturation phase and begins to occupy the ovarian segment called the vitellarium. In this region, the oocyte and nurse cells are arranged in follicles wrapped by follicular cells, forming two separate but interlinked chambers: the oocyte and nurse chambers.

The remaining cystocytes that make up the nurse chamber of the ovarian follicle undergo a growth process that compresses them against each other inside the chamber, thus narrowing the intercellular bridges. This narrowing of the bridges and the disappearance of the microfilaments makes the bridges among the nurse cells difficult to see (Fig. 2c).

Fig. 3 depicts the changes that occur in the intercellular bridges between germ cells.

\section{DISCUSSION}

In the follicles of the polytrophic ovarioles, the nurse cells and the oocyte are the mitotic progeny of a single germ cell called a cystoblast. Thus, the nurse cell/oocyte syncytium is usually an exponential product ( $2 \mathrm{n}$ ) of a single cell (Telfer, 1975; King, 1970; King \& Büning, 1985).

Each cystoblast becomes enveloped by separate somatic cells, originating the cyst with "N" number of cells, being " $\mathrm{N}=2 \mathrm{n}$ ", where " $\mathrm{n}$ " is the number of consecutive incomplete mitotic divisions. The number " $N$ " is species-specific and is determined by a fixed number of synchronous or asynchronous successive mitotic divisions in which the resulting cells do not separate completely (Telfer, 1975).

As the cystoblast begins to divide, intercellular bridges are produced among the cells by incomplete cytokinesis. The bridges are kept open by supporting rings of microfilaments (likely actin), and the width of the bridges is regulated by thick filaments of an unknown nature. These bridges allow cytoplasmic compounds to flow freely among the clone cells and, later, among the nurse cells and the oocyte.

According to King et al. (1982), the cell that will become the oocyte always occupies a central position in the cyst and is always connected to the other cells by a large number of intercellular bridges. However, in the bee species in question (A. mellifera and S. postica), the oocyte cell consistently occupied a basal position in relation to the other cells. Studies on Drosophila melanogaster indicate that the factors decisively influencing oocyte differentiation relate mainly to access of the nucleus of the cystocyte to the cytoplasmic compounds. This access is determined by a cytoplasmic asymmetry established by the cytoskeleton, which is common to all cyst cells that direct the flow of cytosol constituents to a given cell. The cytoskeleton, which consists basically of microtubules in association with motor proteins, still allows for polarized transport of the cloned cell compounds to the oocyte cell in the initial phases of ovogenesis, after the oocyte differentiation process (Cooley \& Theurkauk, 1994).

In the present study, we found that the width and length of the bridges, their supporting elements and the cells' position in relation to them change along the clone forming stages.

It is still unknown if the cytoplasmic factors that interfere in oocyte differentiation are of a quantitative or qualitative nature, but we assume these factors may be only quantitative. This supposition is based on the fact that oocyte 


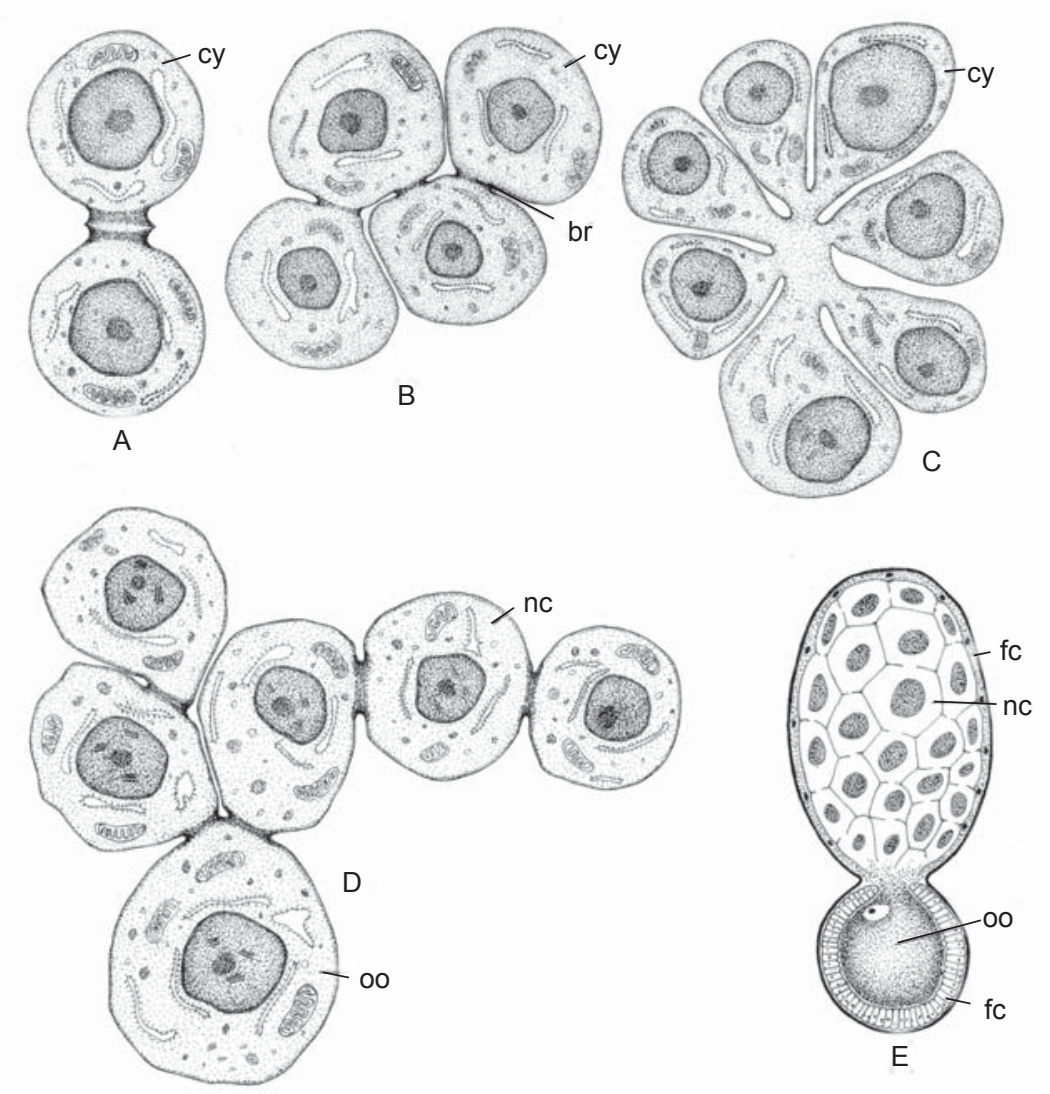

Fig. 3 - Schematic representation of the changes in the bridge rearrangements during cyst and oocyte development: a, b) Beginning of cyst formation; c) Establishment of the fusome; d) Oocyte and nurse cell differentiation; and e) Oocyte and nurse cells connections in the vitellarium. br = bridges; $\mathrm{cy}=$ cystoblast; $\mathrm{fc}=$ follicular cell; $\mathrm{nc}=$ nurse cells; oo $=$ oocyte .

cells communicate directly with a larger number of cystocytes than any other cyst cell does. A competitive relationship may be present, since the cyst possesses a bilateral symmetry, thus originating at least two cystocytes with the same (greater) number of intercellular bridges (Zacaro, 1993).

The oocyte egg should accumulate nutritious and structural material for the initial phases of embryonic development, during which no cellular synthesis occurs. In vertebrates, oocyte meiosis is interrupted in the diplotene stage and the nucleus in this phase synthesizes large amounts of RNA in the loops of the lampbrush chromosomes. In insects with meroistic ovaries, the germinal vesicle (oocyte nucleus) is considered inactive and the nurse cells play the role of lampbrush chromosome loops. Therefore, the presence of nurse cells is the pathway selected by evolution to avoid polyploidization of the germinal vesicle in insects with this type of ovary.

Therefore, the cystoblast or cystocyte cell program may be a selfish one, considering that in primitive (panoistic) ovaries, each primordial germ cell produces only one cell type - the oocyte. However, this selfish behavior is short-lived, for it rapidly becomes altruistic when differentiation between the oocyte and nurse cells takes place (Zacaro, 1993).

The fusome, composed of remainders of the spindles of the cystocyte divisions and characterized by membranous structures (King, 1970), is the point of confluence of the cytoplasm bridges. It is considered a specific organelle and is characterized by containing a complex net of microtubules (Capella \& Hartfelder, 1998) that are able to direct the flow of cytoplasm compounds among the cells. 
Cooley \& Theurkauf (1994) consider the polarized cytoskeleton responsible for directing the flow to the oocyte prior to the completion of cell division. In contrast, the present data indicate that this only occurs after cell division has been completed. However, the authors attribute the role of polarized transport to the microtubules, and the number of microtubules with preferred orientation does not appear to be relevant here.

In addition to determining which cell will become an oocyte, the bridges that interconnect the cystocytes later constitute a pathway by which the products synthesized by the nurse cells reach the oocytes during vitellogenesis.

In conclusion, the bridges that connect the cystocytes change their shape during oogenesis and probably also their specific function, but always maintain their basic function as pathways for intercellular exchanges. The main morphological changes in these bridges involve their gap and length during cyst formation and, after oocyte differentiation, their shape and support of the cytoskeleton.

\section{REFERENCES}

CAPELlA, I. C. S. \& HARTFELDER, K., 1998, Controle hormonal do desenvolvimento pós embrionário dos ovários de Apis mellifera. Anais do Encontro sobre Abelhas, 3: 07-211.

CASSIDY, J. D. \& KING, R. C., 1972, Ovarian development in Habrobracon juglandis (Ashmead) (Hymenoptera: Braconidae). I. The origin and differentiation of the oocytenurse cell complex. The Biol. Bull., 143(3): 483-505.
COOLEY, L. \& THEURKAUF, W. E., 1994, Cytoskeletal functions during Drosophila oogenesis. Science., 266: 590-595.

CRUZ-LANDIM, C., 1978, Structural dynamics of oogenesis in Atta sexdens rubropilosa (Hymenoptera, Formicidae). Rev. Brasil. Biol., 38(2): 363-381.

KING, R. C., 1970, Ovarian development in Drosophila melanogaster. Academic Press, New York, 270p.

KING, R. C., CASSIDY, J. D., ROUSSET, A., 1982, The formation of clones of interconnect cells during gametogenesis in insects. In: R. C. King, H. Akai. Insects ultrastructure. Plenum Press, New York, 2: 3-33.

KING, R. C. \& BÜNING, J., 1985, The origin and functioning of insect oocytes and nurse cells. In: G. A. Kerkut, L. I. Gilbert, Comprehensive insect physiology biochemistry and pharmacology. Pergamon Press, Great Britain, 1: 38-77.

STAURENGO DA CUNHA, M. A., 1981, Números de células nos cistos ovarianos de Scaptotrigona postica Latr. (Hymenoptera, Apidae). Rev. Peru. Ent., 24(1): 67-70.

TELFER, W. H., 1975, Development and physiology of the oocyte-nurse cell syncytium. Adv. Inst. Physiol., 11: 223-319

ZACARO, A. A., 1993, Comportamento dos complexos sinaptonêmicos durante a espermatogênese e ovogênese de Apis mellifera L. (Hymenoptera: Apidae). Dissertação de Mestrado - Universidade Estadual Paulista, Instituto de Biociências, Rio Claro, 141p.

ZACARO,A. A., 1999, Estudo ultra-estrutural da gametogênese (espermatogênese e ovogênese) e análise citogenética de Pediculus humanus L. (Phthiraptera: Pediculidae). Tese de Doutorado - Universidade Estadual Paulista, Instituto de Biociências, Rio Claro, 217p.

ZACARO, A. A., CRUZ-LANDIM, C., 1996, Ovogênese previtelogênica e diferenciação dos ovaríolos prepostura: considerações ultra-estruturais em Apis mellifera. Anais do Encontro Sobre Abelhas, 2: 94-104. 